\title{
Effect of male and female urine on growth and phytochemical constituents of Zea Mays
}

\begin{abstract}
The effect of male and female urine on growth and phytochemical constituents of Zea mays was investigated. The male and female urine were diluted at different concentrations $(50 \mathrm{ml}, 100 \mathrm{ml}, 150 \mathrm{ml}$ and $200 \mathrm{ml})$ and thereafter used to plant the Zea mays. The growth rate was measured in two and four weeks' time after planting for both the male and female urine. The control treatment was without urine. At the end of week four, the leaves were harvested and macerated with the aid of a pestle and mortar for phytochemical analysis. It was observed that both the male and female urines increased the rate of growth and phytochemical constituents of the Zea mays for $50 \mathrm{ml}, 100 \mathrm{ml}$ and $150 \mathrm{ml}$ respectively. High concentration of urine $(200 \mathrm{ml})$ inhibited the growth of Zea mays. The study thus showed that urine is a good source of fertilizer at considerably low concentration. However, high concentration inhibits plant growth.
\end{abstract}

Keywords: Zea mays, phytochemical, human urine, fertilizer, phytochemical constituents, food, drinks, water, general health, chemical fertilizers, toxic levels, nitrogen, fibrous root system

\author{
Volume 2 Issue 6 - 2018
}

\author{
Victor Duniya Sheneni,' Theophilus Boniface \\ Momoh, ${ }^{2}$ Emmanuel Edegbo ${ }^{3}$ \\ 'Department of Biochemistry, Kogi State University, Nigeria \\ ${ }^{2}$ Department of Plant and Biotechnology, Kogi State University, \\ Nigeria \\ ${ }^{3}$ Department of Microbiology, Kogi State University, Nigeria
}

Correspondence: Sheneni Victor Duniya, Department of Biochemistry, Faculty of Natural Sciences, Kogi State University, PMB I008, Anyigba, Nigeria, Tel +234- 80335 I 9009, Email shenanivictor@gmail.com

Received: October 24, 2018 | Published: November |3, 2018

\section{Introduction}

Human urine is an aqueous solution made up of more than $95 \%$ water, with the remaining constituents made up of urea, creatinine, dissolved ions (chloride, sodium, potassium, etc), inorganic and organic compounds or salts. ${ }^{1}$ The amount produced per day varies considerably. Urine comprises only about $1 \%$ of the waste water an individual produces in a day, ${ }^{2}$ thus making the amount about $1-1.5$ liters/person/day. The actual quantity per person per day is affected by factors such as: recent fluid intake (water, and other food/drinks that include water) diet, temperature, blood pressure and general health. ${ }^{3}$ It is a liquid product of the human body secreted by the kidneys, containing large amounts of soluble nutrientss. ${ }^{4}$ Urine is a valuable source of nutrients that has been used since ancient times to enhance the growth of plants, notably leafy vegetables. ${ }^{5}$ The nutrients in urine are in ionic form and their availability has been found to be comparable with chemical fertilizers. ${ }^{6}$ Too much volume of human urine applied on agricultural land as fertilizer, may cause excess sodium in soil and eventually in plant. Sodium inhibits plant growth by interfering with water uptake in root and interfering with the uptake of competitive nutrients. ${ }^{7-9}$ Excess urine in the soil can introduce toxic levels of nutrient into the soil and thus kill the plant as seen in the case of urine fertilizer; the large amount of nitrogen is the main concern. A rule of thumb is that the toxic level of nitrogen is approximately four times the normal fertilization rate. ${ }^{5}$ This provides a large factor of safety for the use of urine fertilizer if nitrogen is kept at an acceptable level. It is generally accepted that other nutrients present in urine will stay at an acceptable level except in rare cases. ${ }^{5}$

In recent years researchers have shown that human urine has a potential to substitute industrial fertilizer due to its large amount of nitrogen $(\mathrm{N})$, phosphorus $(\mathrm{P})$ and potassium $(\mathrm{K})$ contents. ${ }^{10-12}$ Studies also have shown that urine contains some salts, ${ }^{13}$ pathogens, ${ }^{14}$ and pharmaceuticals. ${ }^{15}$ It has been reported that extra urine application inhibits the growth of cabbage, spinach and carrot accompanied with increase in soil electrical conductivity. ${ }^{13}$ Zea mays came from two languages. Zea comes from ancient Greek and is a generic name for cereal and grains. Some scientist believes that Zea stands for "sustaining life". Mays comes from the language Taino, meaning "life giver". Maize is the world's third leading cereal crop, after wheat and rice. It probably originated in Central America, especially Mexico. Maize belongs to the family Poaceae (grass family) and is a tall annual herb with an extensive fibrous root system. Maize provides nutrients for the humans and animals; and serves as a basic raw material for the production of starch, oil, protein, alcoholic beverages, food sweetener and more recently fuel. ${ }^{16}$ Maize kernels are composed of $76 \%$ water, $19 \%$ carbohydrates, $3 \%$ protein, and $1 \%$ fat. ${ }^{17}$ In a 100 -gram serving, maize kernels provide 86 calories and are a good source (10-19\% of the Daily Value) of the B vitamins, thiamin, niacin, pantothenic acid (B5) and folate (right table for raw, uncooked kernels, USDA Nutrient Database). In moderate amounts, they also supply dietary fiber and the essential minerals, magnesium and phosphorus whereas other nutrients are in low amounts. Maize has suboptimal amounts of the essential amino acids tryptophan and lysine, which accounts for its lower status as a protein source. ${ }^{17}$ The indigenous Americans overcame this deficiency with the inclusion of beans in their diet.

\section{Materials and methods}

\section{Description of study area}

The study was conducted between Februarys to March 2018, at the Biological Sciences Department garden, Kogi State University Anyigba, Nigeria. The site is located on $7^{\circ} 15^{1} \mathrm{~N}-7^{\circ} 29^{1} \mathrm{~N}$ and $7^{\circ} 11^{1} \mathrm{E}-7^{\circ} 32^{1} \mathrm{E}$. The site is known with a suitable atmospheric condition, having an annual mean rainfall and temperature of $1250 \mathrm{~mm}$ and $25^{\circ} \mathrm{C}$ respectively. The vegetation is typical of derived savanna with a sandy soil. ${ }^{18}$

\section{Collection of samples}

The soil sample was collected from the premises of Biological Sciences Department garden, Kogi State University Anyigba, Nigeria. The seeds of Zea mays were obtained from Faculty of Agriculture farm, Kogi State University Anyigba, Nigeria. The male and female 
urine were collected from postgraduate students of the department of Biochemistry, Kogi State University Anyigba, and Nigeria after clinical examination.

\section{Sample preparation}

\section{Soil}

Ten kilogram $(10 \mathrm{Kg})$ of soil sample was measured and mixed with water to wet the soil. These were transferred into different polythene bags for the experiments. Each sample was replicated two (5) times.

\section{Urine}

The urine samples were diluted separately with the aid of a calibrated measuring cylinder at different concentrations for both male and female samples ranging from 50,100,150 and $200 \mathrm{ml}$ respectively (i.e. $50 \mathrm{ml}$ of urine $+950 \mathrm{ml}$ of water, $100 \mathrm{ml}$ of urine $+900 \mathrm{ml}$ of water, $150 \mathrm{ml}+850 \mathrm{ml}$ of water and $200 \mathrm{ml}+800 \mathrm{ml}$ of water).

\section{Planting of Seeds}

Seven (7) seeds of Zea mays were sown in each of the prepared pots for both male and female urine samples respectively

\section{Growth parameters}

\section{Plant height}

The height of a plant was measured with meter rule every two weeks. This was recorded for all the treatment. The mean height was determined for all measurement.

\section{Number of leaves}

A plant was randomly selected for all plant and the numbers of leaves per this plant were counted every two weeks and the average number of leaves was calculated for each plant per treatment.

\section{Leaf area}

One plant was selected for each of the treatments. The length and breadth of the leaves of the selected plant were taken with the aid of thread which was later transferred on the meter rule and the average length and breadth was calculated for each plant per treatment. The leaf area of the Zea mays was determined by the formular below;

$$
L A=0.75 \times L \times B
$$

Where $\mathrm{L}=$ Leaf length, $\mathrm{B}=$ Leaf breadth and $0.75=$ Correction factor.

\section{Stem girth}

This was measured using a thread which was later transferred to a meter rule to get the readings.

\section{Quantitative phytochemical analysis}

The leaves of Zea mays were harvested at the end of the experiment. The wet leaves were macerated with the aid of a pestle and mortar and kept in samples bottles for analysis. The phytochemical content (Saponin, tannin, flavonoid, Cardiac glycoside, total phenol, Alkaloid) in each sample was determined using standard methods (AOAC, 1999) at Biochemistry Department Laboratory, Kogi State University Anyigba, and Nigeria.

\section{Data analysis}

Results were expressed as mean \pm standard deviation (SD). The data obtained were analyzed using analysis of variance (ANOVA) (SPSS program, version 20 SPSS Inc., Chicago, IL, USA for windows Computer software Package). The difference between the experimental groups were compared using the Duncan Multiple Range Test. Values of $\mathrm{P}$ less than $0.05(\mathrm{P}<0.05)$ were taken as significant.

\section{Results}

\section{Growth parameters (Two weeks after planting)}

The result of the growth parameter after two weeks of planting is presented in Table 1 . The result shows that there was no significant ( $>0.05$ ) difference in the plant height, number of leaves, leaf area and stem girth for $50 \mathrm{ml}, 100 \mathrm{ml}$ and $150 \mathrm{ml}$ concentrations when compared with the control for both the male and female urine. Whereas, at $200 \mathrm{ml}$ concentration there was a significant $(\mathrm{p}<0.05)$ decreases in the plant height, number of leaves, leaf area and stem girth when compared with the control and the other treatment concentrations $(50 \mathrm{ml}, 100 \mathrm{ml}$ and $150 \mathrm{ml}$ ) for both the male and female urine.

Table I Shows results of two weeks after planting (2WAP)

\begin{tabular}{llllll}
\hline Source of urine & Treatments & Plant height $(\mathbf{c m})$ & Number of leaves $(\mathbf{c m})$ & Leaf area $(\mathbf{c m})$ & Stem girth $(\mathbf{c m})$ \\
\hline Male urine & Control & $7.90 \pm 1.00^{\mathrm{a}}$ & $5.00 \pm 0.00^{\mathrm{a}}$ & $26.05 \pm 3.40^{\mathrm{a}}$ & $0.70 \pm 0.10^{\mathrm{a}}$ \\
& $50 \mathrm{ml} \mathrm{F}$ & $8.25 \pm 0.75^{\mathrm{a}}$ & $5.00 \pm 0.00^{\mathrm{a}}$ & $30.90 \pm 0.25^{\mathrm{a}}$ & $0.90 \pm 0.00^{\mathrm{a}}$ \\
& $100 \mathrm{ml} \mathrm{F}$ & $8.00 \pm 0.00^{\mathrm{a}}$ & $5.00 \pm 0.00^{\mathrm{a}}$ & $30.28 \pm 0.38^{\mathrm{a}}$ & $0.90 \pm 0.20^{\mathrm{a}}$ \\
& $150 \mathrm{ml} \mathrm{F}$ & $5.90 \pm 1.60^{\mathrm{a}}$ & $5.80 \pm 0.00^{\mathrm{a}}$ & $19.23 \pm 5.73^{\mathrm{a}}$ & $0.89 \pm 0.00^{\mathrm{a}}$ \\
& $200 \mathrm{ml} \mathrm{F}$ & $3.05 \pm 1.75^{\mathrm{b}}$ & $3.00 \pm 0.50^{\mathrm{b}}$ & $5.80 \pm 9.30^{\mathrm{b}}$ & $0.10 \pm 0.10^{\mathrm{b}}$ \\
Female urine & Control & $6.40 \pm 0.80^{\mathrm{a}}$ & $4.50 \pm 0.50^{\mathrm{a}}$ & $28.98 \pm 0.68^{\mathrm{a}}$ & $1.60 \pm 0.10^{\mathrm{a}}$ \\
& $50 \mathrm{ml} \mathrm{M}$ & $7.45 \pm 0.45^{\mathrm{a}}$ & $4.50 \pm 0.50^{\mathrm{a}}$ & $28.00 \pm 0.45^{\mathrm{a}}$ & $1.90 \pm 0.00^{\mathrm{a}}$ \\
& $100 \mathrm{ml} \mathrm{M}$ & $5.95 \pm 1.05^{\mathrm{a}}$ & $4.00 \pm 0.00^{\mathrm{a}}$ & $29.65 \pm 0.85^{\mathrm{a}}$ & $1.05 \pm 0.05^{\mathrm{a}}$ \\
& $150 \mathrm{ml} \mathrm{M}$ & $4.05 \pm 1.15^{\mathrm{a}}$ & $4.00 \pm 0.00^{\mathrm{a}}$ & $20.60 \pm 6.80^{\mathrm{a}}$ & $1.65 \pm 0.05^{\mathrm{a}}$ \\
\hline
\end{tabular}

\section{Growth parameters (Four weeks after planting)}

Table 2 shows the result of the growth parameters after four weeks of planting. There was no significant $(\mathrm{p}>0.05)$ difference in the growth parameters (plant height, number of leaves, leaf area and stem girth) for $50 \mathrm{ml}, 100 \mathrm{ml}$ and $150 \mathrm{ml}$ concentrations when compared with control for both the male and female urine. There was a significant $(p<0.05)$ decreases in the growth parameters (plant height, number of leaves, leaf area and stem girth) at urine concentration of $200 \mathrm{ml}$ when compared with the control and the other treatment concentrations $(50 \mathrm{ml}, 100 \mathrm{ml}$ and $150 \mathrm{ml})$ for both the male and female urine. 
Table 2 Shows results of four weeks after planting (4WAP)

\begin{tabular}{|c|c|c|c|c|c|}
\hline Source of urine & treatments & Plant height(cm) & Number of leaves $(\mathrm{cm})$ & Leaf area $(\mathrm{cm})$ & Stem girth $(\mathrm{cm})$ \\
\hline \multirow[t]{5}{*}{ Male urine } & Control & $15.60 \pm 5.60^{\mathrm{a}}$ & $6.50 \pm 0.50^{\mathrm{a}}$ & $54.05 \pm 6.25^{\mathrm{a}}$ & $2.05 \pm 0.35^{\mathrm{a}}$ \\
\hline & $50 \mathrm{ml} \mathrm{M}$ & $19.20 \pm 2.10^{\mathrm{a}}$ & $8.50 \pm 0.50^{\mathrm{a}}$ & $57.15 \pm 7.05^{\mathrm{a}}$ & $3.75 \pm 0.25^{\mathrm{a}}$ \\
\hline & $100 \mathrm{ml} \mathrm{M}$ & $15.95 \pm 1.25^{\mathrm{a}}$ & $7.50 \pm 0.50^{\mathrm{a}}$ & $47.10 \pm 13.90^{\mathrm{a}}$ & $2.50 \pm 0.20^{\mathrm{a}}$ \\
\hline & $150 \mathrm{ml} \mathrm{M}$ & $10.75 \pm 1.05^{\mathrm{a}}$ & $5.00 \pm 0.00^{\mathrm{a}}$ & $20.00 \pm 7.00^{\mathrm{a}}$ & $2.10 \pm 0.10^{\mathrm{a}}$ \\
\hline & $200 \mathrm{ml} \mathrm{M}$ & $1.00 \pm 0.00^{b}$ & $1.00 \pm 0.00^{b}$ & $1.00 \pm 0.00^{\mathrm{b}}$ & $1.00 \pm 0.00^{b}$ \\
\hline \multirow[t]{5}{*}{ Female urine } & Control & $15.45 \pm 0.45^{\mathrm{a}}$ & $6.50 \pm 0.50^{\mathrm{a}}$ & $56.60 \pm 4.70^{\mathrm{a}}$ & $2.35 \pm 0.35^{\mathrm{a}}$ \\
\hline & $50 \mathrm{ml} \mathrm{F}$ & $23.50 \pm 2.50^{\mathrm{a}}$ & $8.50 \pm 0.50^{\mathrm{a}}$ & $68.13 \pm 2.58^{\mathrm{a}}$ & $2.80 \pm 0.10^{\mathrm{a}}$ \\
\hline & $100 \mathrm{ml} \mathrm{F}$ & $19.00 \pm 4.00^{\mathrm{a}}$ & $7.00 \pm 0.00^{\mathrm{a}}$ & $67.40 \pm 4.75^{\mathrm{a}}$ & $3.00 \pm 0.20^{\mathrm{a}}$ \\
\hline & $150 \mathrm{ml} \mathrm{F}$ & $15.05 \pm 1.95^{\mathrm{a}}$ & $6.00 \pm 1.00^{\mathrm{a}}$ & $53.10 \pm 3.50^{\mathrm{a}}$ & $3.75 \pm 0.25^{\mathrm{a}}$ \\
\hline & $200 \mathrm{ml} \mathrm{F}$ & $1.00 \pm 0.00^{\mathrm{b}}$ & $1.10 \pm 0.00^{\mathrm{b}}$ & $1.10 \pm 0.00^{\mathrm{b}}$ & $1.00 \pm 0.00^{\mathrm{b}}$ \\
\hline
\end{tabular}

Table 3 Result of phytochemical constituents for male and female urine at different concentrations

\begin{tabular}{|c|c|c|c|c|c|c|}
\hline Treatments & $\begin{array}{l}\text { Flavonoid } \\
\text { (mg/g) }\end{array}$ & $\begin{array}{l}\text { Tannins } \\
(\mathrm{mg} / \mathrm{g})\end{array}$ & $\begin{array}{l}\text { Saponins } \\
(\mathrm{mg} / \mathrm{g})\end{array}$ & $\begin{array}{l}\text { Cardiac glycoside } \\
(\mathrm{mg} / \mathrm{g})\end{array}$ & $\begin{array}{l}\text { Total phenol } \\
\text { (mg/g) }\end{array}$ & $\begin{array}{l}\text { Alkaloid } \\
(\mathrm{mg} / \mathrm{g})\end{array}$ \\
\hline Sample A(control) & $37.56 \pm 0.23^{g}$ & $1.98 \pm 0.03^{f}$ & $3.54 \pm 0.10^{g}$ & $0.00 \pm 0.00^{e}$ & $188.83 \pm 1.02^{\mathrm{e}}$ & $0.3 \mathrm{I} \pm 0.0 \mathrm{I}^{\mathrm{f}}$ \\
\hline Sample B(50ml M) & $81.78 \pm 0.00^{\mathrm{b}}$ & $6.11 \pm .00^{b}$ & $19.64 \pm 0.20^{\mathrm{a}}$ & $0.01 \pm 0.00^{\text {de }}$ & $271.99 \pm 1.53^{d}$ & $0.76 \pm 0.02^{\mathrm{e}}$ \\
\hline Sample C(I00ml M) & $79.11 \pm 0.11^{d}$ & $1.54 \pm .03^{g}$ & $15.04 \pm 0.00^{c}$ & $0.0 \mathrm{I} \pm 0.00^{\mathrm{cd}}$ & $484.74 \pm 0.00^{\mathrm{a}}$ & $0.9 \mathrm{I} \pm 0.0 \mathrm{I}^{\mathrm{d}}$ \\
\hline Sample D(I50ml M) & $48.26 \pm 0.17^{f}$ & $3.33 \pm 0.03^{d}$ & $8.24 \pm 0.20^{f}$ & $0.02 \pm 0.00^{\mathrm{bc}}$ & $501.58 \pm 1.53^{\mathrm{a}}$ & $1.20 \pm 0.00^{\mathrm{b}}$ \\
\hline Sample $E(50 \mathrm{ml} \mathrm{F})$ & $98.89 \pm 0.00^{\mathrm{a}}$ & $4.67 \pm 0.02^{c}$ & $16.84 \pm 0.20^{b}$ & $0.03 \pm 0.00^{\mathrm{bc}}$ & $263.83 \pm 1.53^{d}$ & $0.95 \pm 0.0 \mathrm{I}^{\mathrm{c}}$ \\
\hline Sample F(I00ml F) & $79.94 \pm 0.17^{c}$ & $2.22 \pm 0.03^{\mathrm{e}}$ & $13.04 \pm 0.00^{d}$ & $0.03 \pm 0.00^{b c}$ & $319.95 \pm 1.53^{c}$ & $\mathrm{I} .23 \pm 0.0 \mathrm{I}^{\mathrm{b}}$ \\
\hline Sample G(I50ml F) & $58.50 \pm 0.06^{e}$ & $8.47 \pm 0.03^{a}$ & $9.24 \pm 0.20^{e}$ & $0.04 \pm 0.00^{\mathrm{a}}$ & $345.60 \pm 16.98^{b}$ & $1.40 \pm 0.00^{\mathrm{a}}$ \\
\hline
\end{tabular}

\section{Phytochemical constituents}

The result of phytochemical constituents for male and female urine at different concentrations is presented in Table 3 . The result shows that there was a significant $(\mathrm{p}<0.05)$ difference in all the phytochemical constituents (flavonoid, tannin, saponin, cardiac glycoside, total phenol and alkaloid). $50 \mathrm{ml}$ concentration for male urine recorded the highest value $(98.89 \pm 0.00 \mathrm{mg} / \mathrm{g})$ for the flavonoid content while the control recorded the lowest $(37.56 \pm 0.23 \mathrm{mg} / \mathrm{g})$. For tannins, $150 \mathrm{ml}$ concentration for male urine recorded the highest value $(8.47 \pm 0.03 \mathrm{mg} / \mathrm{g})$ while $100 \mathrm{ml}$ concentrations for female urine recorded the lowest value $(1.54 \pm 0.03 \mathrm{mg} / \mathrm{g})$. Saponin recorded the highest value $(19.64 \pm 0.20 \mathrm{mg} / \mathrm{g})$ at $50 \mathrm{ml}$ concentration for female urine while the control recorded the lowest value $(3.54 \pm 0.10 \mathrm{mg} / \mathrm{g})$. Cardiac glycoside recorded the highest value $(0.04 \pm 0.00 \mathrm{mg} / \mathrm{g})$ at $150 \mathrm{ml}$ concentration for male urine while the control recorded the lowest value $(0.00 \pm 0.00 \mathrm{mg} / \mathrm{g})$. Total phenol recorded the highest value $(501.58 \pm 1.53 \mathrm{mg} / \mathrm{g})$ at $150 \mathrm{ml}$ concentration for female urine while the control recorded the lowest value $(188.83 \pm 1.02 \mathrm{mg} / \mathrm{g})$. Alkaloid recorded the highest value $(1.40 \pm 0.00 \mathrm{mg} / \mathrm{g})$ at $150 \mathrm{ml}$ concentration for male urine while the control recorded the lowest value $(0.31 \pm 0.01 \mathrm{mg} / \mathrm{g})$.

\section{Discussion}

Urine is a valuable source of nutrients that has been used since ancient times to enhance the growth of plants, notably leafy vegetables. ${ }^{5}$ In recent years researchers have shown that human urine has a potential to substitute industrial fertilizer due to its large amount of nitrogen $(\mathrm{N})$, phosphorus $(\mathrm{P})$ and potassium $(\mathrm{K})$ contents. ${ }^{10-12}$ Studies also have shown that urine contains some salts, ${ }^{13}$ pathogens, ${ }^{13,14}$ and pharmaceuticals. ${ }^{15}$ It has been reported that extra urine application inhibits the growth of cabbage, spinach and carrot accompanied with increase in soil electrical conductivity. ${ }^{13}$ In this studies, it was observed that urine increased growth parameters (plant height, number of leaves, leaf area and stem girth) of Zea mays for both male and female urine respectively. This is in line with the work of Jonsson et al. ${ }^{5}$ who showed that urine is a good source of nutrient for growth of plants. All the treatments with $200 \mathrm{ml}$ concentration of urine died two weeks after planting, few with retarded growth. This result is coinciding with the result of Mnkeni et al. ${ }^{13}$ and Jonsson et al. ${ }^{5}$ who reported that excess urine in soil inhibits growth and kill plants respectively. This is also in line with the work of Dora et al. ${ }^{19}$ where excess urine application affected nitrogen concentration in plant shoot and root. There were no significant differences in the male and female urine. No literature showing the differences in male and female urine has been documented yet. The phytochemical analysis revealed the presence of flavonoid, tannin, saponin, cardiac glycoside, total phenol and alkaloid in high concentration. It was observed in this study that an increase in phytochemical constituent decrease the growth parameters of plant. This is in line with the study carried out by of Alfred et al. ${ }^{20}$ on the chemical analysis, assessment of human male and female urine for its fertilizing potential in agriculture. The study reported that application of human male and female urine reduces the availability of nitrogen in plants. At concentrations of 200 and $1,200 \mathrm{ml}$, phytochemical constituents (flavonoid, tannins, saponins, cardiac glycoside and total phenol) become a threat to human health when it is been consume. This is in line with the present study which shows that at 50,100 and $150 \mathrm{ml}$ of urine concentration; the crop is still being healthy for human consumption. ${ }^{21-23}$

\section{Conclusion}

The present study has shown that urine increases growth of Zea mays and its phytochemical constituents at considerably low 
concentrations. However, a high concentration of urine inhibits/ kills the growth of plant. Therefore, there is a need for further testing before it can be recommended for use by agricultural organizations.

\section{Acknowledgements}

None.

\section{Conflict of interest}

The author declares there is no conflict of interest.

\section{References}

1. Richert A, Gensch R, Joensson H. Practical Guidance on the Use of urine in Crop Production. Stockholm. Stockholm Environment Institute (SEI). 2010;40:39-41.

2. Jemba PK. Excretion and ecotoxicity of pharmaceutical and personal care product in the environment. Ecotoxicology and Environmental Safety. 2006;63(1):113-130.

3. Ivy Rose NM. The Human Urine. Paper presented at the 22nd International Symposium on Ecological sanitation. Berlin German. 2003;39:10-25.

4. Gensch RM. Urine Excretion and Nutrient metabolism. Toxicology and Environmental Safety. 2015;50:13-30.

5. Jonsson H, Stinzing AR, Vinneras B, et al. Guidelines on the Use of urine in Crop Production. Reuse: Issues Technologies and applications. 2004:959-962.

6. Richert-Stintzing A, Rodhe L, Akerhielm H. Human urine as fertilizerplant nutrients, application technique and environmental effects. Swedish Institute of Agricultural and Environmental Engineering, Sweden. 2001;68:191-198.

7. Asano T, Burton FL, Leverenz HL. Water carbamazepine and ibuprofen applied by urine fertilization. Science Total Environment. 2007;408:19021908.

8. Franzen D. Managing Saline Soils in North Dakota. NDSU Extension Service, North Dakota State University, Fargo, ND, 58105, SF-1087 (Revised). 2007:1-11.

9. Lee TS. Irrigation System and Practices in Challenging Environments. Environmental Safety. 2012;50:169-190.

10. Pradhan SK, Nerg AM, Sjöblom A, et al. Use of Cabbage (Brassica Oleracea) Impacts on Chemical, Microbial, and Flavor Quality. Journal of Agricultural and Food Chem. 2007;55(21):8657-8663.
11. Pradhan SK, Pitkanen S, Heinonen-Tanski H. Fertilizer value of urine in pumpkin (Cucurbita maxima L.) cultivation. Journal of Agriculture and Food Chem. 2009;18(1):57-68.

12. Pradhan SK, Holopainen JK, Heinonen-Tanski H. Stored Human urine Supplemented with wood ash as fertilizer in tomato (Solanumly copersicum) cultivation and its impacts on fruit Yield and quality. Journal of Agricultural and Food Chemistry. 2010;57:7612-7617.

13. Mnkeni PNS, Austin A, Kutu FR. Preliminary studies on the evaluation of human urine as a source of nutrients for vegetables in the Eastern Cape Province, South Africa. Proceedings of the 10th International Ecological Sanitation Conference, Pretoria, South Africa. 2006;418-426.

14. Höglund C. Evaluation of microbial health risks associated with the reuse of source human urine as a source of nutrients for vegetables in the Eastern Cape Province, South Africa. 3rd International Ecological Sanitation Conference, Durban, South Africa. 2001:18-26.

15. Winker M, Clemens J, Reich M. Ryegrass uptake of Urine and Faeces in Crop Production. 2010;45:11-21.

16. Ranere, Anthony J, Piperno. The cultural and chronological context of early Holocene maize and squash domestication in the Central Balsas River Valley, Mexico (PDF). Proceedings of the National Academy of Sciences.2009;106(13):5014-5018.

17. Matsuoka Y, Vigouroux Y, Goodman MM, et al. A single domestication for maize shown by multilocus microsatellite genotyping. Proceedings of the National Academy of Sciences. 2002;99(9):6080-6084.

18. Ifatimehin RE. The vegetations of the West Africa Countries. Proceedings of the 5th International Conference, Abuja, Nigeria. 2012:418-426.

19. Dora R, Mathias T, Walter Y. Effect of Human Urine on Nitrogen concentration. Journal of Agriculture and Food Chem. 2003;8:7-8.

20. Alfred W, Palm O, Biebow M. Chemical assessment of Human urine. Water Research. 2015;10:145-142.

21. Rosen CJ, Bierman PM, Eliason RD. Soil Test Interpretation and Fertilizer Management for Laws, Turf, Garden, and Landscape Plants. Stockholm. 2008;38(6):17-25.

22. AOAC. Association of Official Analytical Chemists. Official methods of analysis. 25th edition. VA: Arlington; 1999.

23. Heinonen-Tanski H, Sjöblom A, Fabritius H, et al. Pure human urine is a Good fertilizer for cucumbers. Bioresource Technolog. 2007;98(1):214 217. 